\section{Loyalitas Kreativitas \\ Aldi Masyarakat Kreatif}

P-ISSN 2722-2101, E-ISSN 2722-4201

Program Studi Ekonomi Manajemen Universitas Pamulang

Jurnal LOKABMAS Kreatif Vol.02,No.03.Nov 2021 Hal.52-64

Email:jurnalkreatif.manajemen@gmail.com

\title{
PEMANFAATAN YOUTUBE SEBAGAI MEDIA PEMBELAJARAN KREATIF TANPA BATAS DITENGAH PANDEMI COVID 19 DI YAYASAN AL-KAMILAH
}

\author{
Susilawati, Hasanudin, Devi Fitria Wilandari, Ratna Dumilah, Rizka Putri Anggraeni \\ Dosen Prodi Manajemen Fakultas Ekonomi Universitas Pamulang
Email : dosen02625@unpam.ac.id, dosen02482@unpam.ac.id, dosen02529@unpam.ac.id, dosen02209@unpam.ac.id, dosen02520@unpam.ac.id

\begin{abstract}
ABSTRAK
Tujuan dari kegiatan Pengabdian Kepada Masyarakat ini adalah untuk melaksanakan salah satu Tri Dharma Perguruan Tinggi. Selain itu, melalui kegiatan Pengabdian Kepada Masyarakat ini, keberadaan perguruan tinggi diharapkan dapat memberikan kontribusi besar kepada pengembangan dan penerapan keilmuan dalam masyarakat.

Metode yang digunakan pada Pengabdian Kepada Masyarakat ini adalah tim pelaksana mengunjungi Yayasan Al-Kamilah yang beralamat di jalan Serua Raya Rt 03 Rw 05, Kel. Serua, Kec. Bojongsari - Depok serta melakukan Sosialisasi dan Edukasi yaitu suatu tindakan, proses, hasil atau pernyataan yang lebih baik. Dalam hal ini menunjukkan adanya kemajuan, peningkatan pertumbuhan, evolusi atas berbagai kemungkinan, berkembang atau peningkatan atas sesuatu.

Hasil kegiatan Pengabdian Kepada Masyarakat ini adalah bertambahnya keilmuan dan keterampilan remaja Yayasan Al-Kamilah, khususnya di bidang Pemanfaatan Youtube Sebagai Media Pembelajaran Kreatif Tanpa Batas, baik dimasa normal maupun dimasa Pandemi Covid 19 seperti sekarang ini. Ilmu yang didapatkan pada kegiatan Pengabdian Kepada Masyarakat ini diharapkan mampu memberikan semangat dalam menyampaikan pengetahuan dan memberikan motivasi serta berkontribusi bagi generasi muda, baik di lingkungan sekolah, kampus maupun masyarakat.

Supaya PKM ini tepat sasaran, maka perlu diperhatikan metode pelaksanaan PKM. Adapun metode pelaksanaan PKM ini adalah dengan cara: 1. Metode Ceramah / Presentasi, 2. Metode Tanya Jawa. 3. Sharing Session Tentang Pemanfaatan Youtube Sebagai Media Pembelajaran Kreatif Tanpa Batas. Sharing session ini diberikan kepada para peserta guna mendorong remaja Yayasan Al-Kamilah untuk lebih aktif dalam meningkatkan kreatif dan kualitas pembelajaran melalui media sosial Youtube. Luaran dari hasil Pengabdian Kepada Masyarakat ini akan di publikasi pada jurnal internal kampus Pengabdian Kepada Masyarakat dan berupa artikel di media sosial.
\end{abstract}

Kata kunci : Media Pembelajaran Kreatif, Pandemi Covid 19, Youtube

\section{ABSTRACT}

The purpose of this Community Service activity is to implement one of the Tri Dharma of Higher Education. In addition, through this Community Service activity, the existence of universities is expected to make a major contribution to the development and application of science in society.

The method used in this Community Service is the implementation team visits the AlKamilah Foundation which is located at Jalan Serua Raya Rt 03 Rw 05, Kel. Serua, District. 
Bojongsari - Depok as well as conducting socialization and education, namely a better action, process, result or statement. In this case, it indicates progress, increased growth, evolution of various possibilities, development or improvement of something.

The result of this Community Service activity is the increase in the knowledge and skills of the Al-Kamilah Foundation's youth, especially in the field of Utilizing Youtube as a Creative Learning Media Without Boundaries, both during normal times and during the Covid 19 Pandemic as it is today. The knowledge gained in this Community Service activity is expected to be able to provide enthusiasm in conveying knowledge and provide motivation and contribute to the younger generation, both in schools, campuses and the community.

In order for this PKM to be right on target, it is necessary to pay attention to the method of implementing PKM. The method of implementing this PKM is by: 1. Lecture / Presentation Method, 2. Ask Java Method. 3. Sharing Session About Using Youtube as a Creative Learning Media Without Boundaries. This sharing session was given to participants to encourage AlKamilah Foundation youth to be more active in improving creativity and learning quality through Youtube social media. The output of this Community Service result will be published in the internal journal of the Community Service campus and in the form of articles on social media.

\section{Keywords: Creative Learning Media, Covid 19 Pandemic, Youtube}

\section{PENDAHULUAN}

Masa Pandemi Corona Virus Disease19 atau lebih dikenal dengan Covid-19 saat ini masih melanda berbagai negara di dunia, termasuk Indonesia. Pandemi tersebut sangat mempengaruhi kehidupan masyarakat di berbagai bidang seperti bidang sosial, pariwisata, ekonomi dan pendidikan. Pandemi COVID-19 telah menganggu seluruh bidang kehidupan, termasuk juga bidang pendidikan disemua jenjang.

Mudahnya penularan virus ini, menjadikan pemerintah mengeluarkan peraturan dengan melakukan berbagai cara dan tindakan dalam mengatasi COVID19 ,peraturan tersebut diantaranya adalah dengan melakukan pembatasan sosial dan menjaga jarak fisik. Pemberlakuan pembatasan sosial dan menjaga jarak menjadi dasar pelaksanaan belajar di rumah. Dalam kegiatan belajar dari rumah, peserta didik memanfaatkan teknologi informasi untuk proses belajarnya. Penyelenggaraan proses belajar mengajar dilakukan secara DARING (dalam jaringan) sesuai dengan arahan dari kementerian pendidikan dan kebudayaan Republik Indonesia, hal tersebut terdapat dalam surat Edaran yang 2 dikeluarkan oleh Mendikbud Republik
Indonesia nomor 3 tahun 2020, serta surat Edaran Nomor 4 Tahun 2020 yang langsung diturunkan oleh Menteri Pendidikan dan Kebudayaan Indonesia Bapak Nadiem Anwar Makarim yang berisikan tentang pelaksanaan pendidikan dalam masa darurat penyebaran COVID-19. Didalam surat edaran dijelaskan bahwa proses kegiatan belajar dilakukan di rumah melalui pembelajaran jarak jauh (PJJ) atau DARING.

Pembelajaran DARING merupakan pembelajaran yang dilakukan secara online, menggunakan aplikasi pembelajaran maupun jejaring sosial (Syafni Ermayulis, S.Pd., M.Pd 2020). Pembelajaran daring merupakan pembelajaran yang dilakukan tanpa melakukan tatap

muka, tetapi melalui Platform yang tersedia. Kejelian dan ketelitian peserta didik dalam menerima dan mengolah informasi yang diberikan secara DARING merupakan hal yang ditekankan dalam pembelajaran DARING (Riyana, 2019). Selain kejelian dan ketelitian peserta didik, guru juga harus memiliki kemampuan dalam memanfaatkan TIK.

Permendikbud nomor 68 tahun 2014 mengenai peran pendidik TIK dan pendidik keterampilan Komputer dan pengelolaan 
informasi dalam implementasi kurikulum 2013 yang telah mendukung guru dalam proses pembelajaran dengan menggunakan teknologi media DARING. Selain dengan tuntutan kondisi pandemi COVID-19 yang terjadi saat ini pembelajaran DARING sangat dibutuhkan untuk keterlaksanaan proses pembelajaran. Guru sebagai pendidik harus mampu melakukan inovasi dalam pembelajaran untuk melakukan pembelajaran DARING sesuai standar kualifikasi akademik dan kompetensi pendidik. Kompetensi pedagogik dan kompetensi profesional menuntut guru/dosen mampu menggunakan dan memanfaatkan TIK untuk kegiatan pembelajaran. Penggunaan 3 media pembelajaran yang memanfaatkan teknologi untuk proses pembelajarannya sangat dibutuhkan pada pembelajaran DARING. Dengan menggunakan media pembelajaran dalam jaringan diharapkan pembelajaran akan menjadi efektif, efisien dan inovatif saat masa pandemi COVID-19.

Selama proses pembelajaran DARING, banyak sekali hambatan yang dihadapi pengajar maupun peserta didik. Salah satu hambatan yang dihadapi yaitu siswa sering mengalami kesulitan dalam memahami instruksi dari pendidik. Apalagi instruksi tersebut hanya berupa tulisan yang kebanyakan dikirimkan melalui WhatsApp atau pesan singkat. Oleh karena itu pendidik dituntut untuk memanfaatkan teknologi yang ada agar proses pembelajaran dapat tercapai saat pembelajaran DARING. Untuk mencapai proses pembelajaran yang di maksud media yang dapat digunakan dalam mensiasati pembelajaran DARING salah satunya yaitu dengan menggunakan Youtube.

Youtube merupakan situs berbagi video, Youtube didirikan oleh 3 orang yaitu Chad Hurley, Steve Chen dan Jawed Karim di Amerika pada februari tahun 2005. Saat ini Youtube bisa diunduh di google playstore maupun di web dan dapat diakses secara gratis menggunakan jaringan internet. video klip, film, tv dan video buatan para penggunanya sendiri merupakan videovideo yang ada di Youtube (Tjanatjantia, 2013).

Salah satu layanan yang terdapat didalam Youtube antara lain pengguna dapat mengupload video dan membagikannya serta dapat diakses oleh pengguna lain diseluruh dunia. Video blog merupakan bentuk suatu media informasi yang dibuat secara sederhana yang di gunakan secara DARING melalui channel Youtube (Yudhi \& Priana, 2017). Hal tersebut bisa dijadikan sebagai media pendukung 4 dalam pembelajaran DARING karena Youtube memiliki beberapa keunggulan guna menciptakan pembelajaran yang menarik dan menyenangkan.

Youtube merupakan situs yang sangat populer pada saat ini yang mampu dimanfaatkan dalam pendidikan. Keunggulan Youtube dalam pendidikan yaitu penggunaanya sangat praktis yang mudah digunakan dan diikuti oleh peserta didik dan pengajar, Youtube memberikan informasi mengenai perkembangan ilmu diberbagai bidang pendidikan serta Youtube menawarkan fasilitas interaktif untuk berdiskusi.

Untuk membuka wacana pengetahuan tentang Pemanfaatan Youtube Sebagai Media Pembelajaran Kreatif Tanpa Batas dikalangan remaja, terutama dimasa pandemi seperti ini, kami tim pelaksana kegiatan PKM (Pengabdian Kepada Masyarakat) Prodi Manajemen Fakultas Ekonomi Universitas Pamulang akan bekerja sama dengan Yayasan Al-Kamilah untuk mensosialisasikan hal ini kepada para remaja Yayasan Al-Kamilah. Tema yang kami ambil adalah "Pemanfaatan Youtube Sebagai Media Pembelajaran Kreatif Tanpa Batas Ditengah Pandemi Covid 19 di Yayasan Al-Kamilah."

\section{PERUMUSAN MASALAH}

Berdasarkan analisis situasi permasalahan yang telah diutarakan diatas kami berinisiatif untuk membentuk pengabdian masyarakan bagi Ketua dan segenap para anggota Yayasan Al-Kamilah 
dijalan Serua Raya Rt 03 Rw 05, Kel. Serua, Kec. Bojongsari - Depok melalui progam dengan Cara mendeskripsikan dan edukasi Pemanfaatan Youtube Sebagai Media Pembelajaran Kreatif Tanpa Batas Ditengah Pandemi Covid 19 agar mereka memiliki pemahaman dan pandangan yang baik bagaimana upaya agar tetap kreatif dan berkreasi tanpa batas dengan menggunakan youtube sebagai media sosial dengan baik dan benar pada masa pandemi Covid-19.

Berdasarkan analisis situasi permasalahan di atas, maka tersusunlah rumusan masalah dalam kegiatan PKM ini, sebagai berikut : Bagaimanakah cara mendeskripsikan pemanfaatan youtube sebagai media pembelajaran kreatif tanpa batas di tengah Covid 19 dengan baik dan benar?

\section{TUJUAN PENGABDIAN KEPADA}

\section{MASYARAKAT}

1. Mensosialisasikan bagaimana menggunakan media Daring Youtube di masa pandemi Covid 19 di Yayasan Al-Kamilah.

2. Memberikan Edukasi Terhadap Para remaja pada pembelajaran Daring di masa pandemi COVID-19 di Yayasan Al-Kamilah.

3. Membuka pemikiran dan pandangan dalam upaya penanggulangan dampak pandemi melalui tata cara belajar secara Daring dengan Pemanfaatan Youtube Sebagai Media Pembelajaran Kreatif Tanpa Batas Ditengah Pandemi Covid 19 di Yayasan Al-Kamilah.

4. Mempengaruhi seluruh pengurus Yayasan Al-Kamilah dalam membentuk suatu perilaku dan memotori gerakan sosial yang bertujuan menanggulangi pandemi Covid-19.

\section{MANFAAT PENGABDIAN KEPADA MASYARAKAT}

1. Mewujudkan salah satu Tri Dharma Perguruan Tinggi yaitu Pengabdian kepada masyarakat sehingga mampu mencari permasalahan dalam masyarakat.

2. Memperoleh bantuan tenaga dan pikiran dalam meningkatkan pemahaman dan sosialisasi tentang pemanfaatan youtube sebagai media pembelajaran kreatif tanpa batas ditengah pandemi Covid 19 yang baik dan benar.

3. Memperoleh informasi tentang sosialisasi pembelajaran secara daring dengan memanfaatkan youtube sebagai media pembelajaran kreatif tanpa batas ditengah pandemi Covid 19 yang dilakukan oleh individu atas kesadaran sendiri.

4. Membantu membentuk perilaku dan memotori gerakan sosial yang bertujuan menanggulangi pandemi Covid 19.

\section{TINJAUAN PUSTAKA}

\section{Pengertian Belajar dan Pembelajaran}

Belajar merupakan proses atau usaha yang dilakukan oleh para individu guna memperolehperubahan tingkah laku berupa pengetahuan, keterampilan, sikap serta nilai yang positif untuk pengalaman yang telah dipelajari (Zulyadani,2016).

Interaksi antara sesorang dengan lingkungan merupakan proses belajar yang terjadi kapan saja dan dimana saja (Arsyad, 2019: 1). Selain itu, belajar juga dilakukanoleh masing-masing individu secara terus menerus karena dalam kehidupanterdapat kejadian atau peristiwa yang bisa dijadikan pembelajaran.

Pembelajaran hakikatnya adalah proses menata, mengorganisasi lingkungan disekitar peserta didik untuk menumbuhkan dan mendorong terjadinya proses pembelajaran (Pane \& Dasopang, 2017). Pembimbingan dan pengarahan adalah bentuk proses pembelajaran yang dilakukan oleh guru untuk proses belajar. Maka dalam proses pembelajaran terbangun dari interaksi guru dan peserta didik. Hal tersebut sejalan dengan pendapat (Putria dkk, 2020) 
bahwa dalam proses pembelajaran akan melibatkan kegiatan belajar dan mengajar dan akan menentukan keberhasilan siswa selain itu juga untuk mencapai tujuan pendidikan.

\section{Pengertian Pembelajaran Daring}

Pembelajaran daring merupakan metode belajar yang menggunakan model interaktif berbasis internet dan Learning Manajemen System (LMS). Seperti menggunakan Zoom, Google Meet, dan lainnya.

Pembelajaran DARING adalah sistem pembelajaran yang dilaksanakan dengan tanpa tatap muka langsung tetapi dengan bantuan platform untuk membantu proses belajar mengajar pada pembelajaran jarak jauh (Handarini, 2020). Pembelajaran dilaksanakan dengan menggunakan teknologi informasi dan komunikasi untuk menunjang kegiatan belajar mengajar agar proses pembelajaran tetap berlangsung.

Menurut Moore, Dickson-Deane, \& Galyen (2011) Pembelajaran daring merupakan pembelajaran yang menggunakan jaringan internet dengan aksesibilitas, konektivitas, fleksibilitas, dan kemampuan untuk memunculkan berbagai jenis interaksi pembelajaran.

Maka dapat disimpulkan bahwa pembelajaran DARING merupakan pembelajaran jarak jauh yang dilaksanakan menggunakan smartphone, tablet, komputer yang terkoneksi dengan internet.

\section{Pengertian Youtube}

Youtube merupakan situs web berbagi video, Youtube didirikan di Amerika pada februari tahun 2005. Saat ini Youtube bisa diunduh di google playstore maupun di web dan dapat diakses secara gratis menggunakan jaringan internet. Video klip, film, tv dan video buatan para penggunanya sendiri merupakan video- video yang ada di Youtube (Tjanatjantia, 2013).

Salah satu layanan yang terdapat didalam Youtube antara lain pengguna dapat mengupload video dan membagikannya serta dapat diakses oleh pengguna lain diseluruh dunia. Video blog merupakan bentuk suatu media informasi yang dibuat secara sederhana yang di gunakan secara DARING melalui channel Youtube (Yudhi \& Priana, 2017).

Karakteristik Youtube dikelompokkan menjadi 5 bagian yaitu tidak memiliki batas durasi dalam pengungahan video, memiliki sistem keamanan yang mulai akurat, berbayar, memiliki sistem offline dan memiliki editor sederhana (Faiqah,dkk 2016). Hal ini yang membedakan Youtube dengan aplikasi lain karena memiliki karakteristik yang membuat banyak orang menggunakannya. Selain itu Youtube memiliki keunggulan sebagai media pembelajaran.

Media pembelajaran Youtube memiliki keunggulan di dalam dunia pendidikan yaitu Youtube merupakan situs paling populer didunia internet dan memberikan edit value terhadap pendidikan, mudah digunakan oleh peserta didik dan guru, memberikan informasi pendidikan, memfasilitasi untuk berdikusi, memiliki fitur share di jejaring sosial dan gratis (Musarofah, 2019).

\section{Pengertian Pemanfaatan}

Pemanfaatan berasal dari kata dasar manfaat yang berarti guna atau bisa di diartikan berfaedah. Pemanfaatan memiliki makna proses, cara atau perbuatan memanfaatkan (Kamus Bahasa Indonesia Kontemporer, 2002 : 928). Pemanfaatan adalah suatu kegiatan, proses, cara atau perbuatan menjadikan suatu yang ada menjadi bermanfaat. Istilah pemanfaatan berasal dari kata dasar manfaat yang berarti faedah, yang mendapat imbuhan pe-an yang berarti proses atau perbuatan memanfaatkan (Poerwadarminto , 2002 : 125). Pengertian pemanfaatan dalam penelitian ini adalah turunan dari kata "manfaat", yaitu suatu perolehan atau pemakaian hal-hal yang berguna baik dipergunakan secara langsung maupun tidak langsung agar dapat bermanfaat. 


\section{Pengertian Kreatif}

Kreatif merupakan suatu kemampuan yang dimiliki seseorang "atau sekelompok orang" yang memungkinkan mereka menemukan pendekatan-pendekatan atau terobosan baru dalam menghadapi situasi atau masalah tertentu yang biasanya tercermin dalam pemecahan masalah dengan cara yang baru dan juga unik yang berbeda dan lebih baik dari sebelumnya. Menurut (Utami Munandar “1992:47”) bahwa kreatif ialah kemampuan untuk membuat kombinasi baru, berdasarkan data, informasi atau unsur-unsur yang ada. Sedangkan menurut Menurut Clarkl Monstakis mengatakan bahwa kreatif merupakan pengalaman dalam mengekspresikan dan mengaktualisasikan identitas individu dalam bentuk terpadu antara hubungan diri sendiri, alam dan orang lain.

Berdasarkan pendapat para ahli maka dapat disimpulkan kreatif ialah suatu kemampuan seseorang dalam menciptakan hal-hal baru dengan cara-cara baru yang tidak biasa atau berbeda dari yang telah dilakukan orang lain sebelum nya.

\section{Pengertian Covid-19}

Coronavirus Disease 2019 (COVID19) adalah penyakit menular yang disebabkan oleh Severe Acute Respiratory Syndrome Coronavirus 2 (SARS-CoV-2). SARS-CoV-2 merupakan coronavirus jenis baru yang belum pernah diidentifikasi sebelumnya pada manusia (KemenKes, 2020). Ada setidaknya dua jenis coronavirus yang diketahui menyebabkan penyakit yang dapat menimbulkan gejala berat seperti Middle East Respiratory Syndrome (MERS) dan Severe Acute Respiratory Syndrome (SARS). Tanda dan gejala umum infeksi COVID-19 antara lain gejala gangguan pernapasan akut seperti demam, batuk dan sesak napas. Masa inkubasi rata- rata 5-6 hari dengan masa inkubasi terpanjang 14 hari. Pada kasus COVID- 19 yang berat dapat menyebabkan pneumonia, sindrom pernapasan akut, gagal ginjal, dan bahkan kematian
Indonesia melaporkan kasus pertama pada tanggal 2 Maret 2020. Kasus meningkat dan menyebar dengan cepat di seluruh wilayah Indonesia. Sampai dengan tanggal 3 Novemer 2020 Kementerian Kesehatan melaporkan 418.375 kasus konfirmasi COVID-19 dengan 14.146 kasus meninggal. Dilihat dari situasi penyebaran COVID-19 yang sudah hampir menjangkau seluruh wilayah provinsi di Indonesia dengan jumlah kasus dan/atau jumlah kematian semakin meningkat dan berdampak pada aspek politik, ekonomi, sosial, budaya, pertahanan dan keamanan, serta kesejahteraan masyarakat di Indonesia, Pemerintah Indonesia telah menetapkan Keputusan Presiden Nomor 11 Tahun 2020 tentang Penetapan Kedaruratan Kesehatan Masyarakat Corona Virus Disease 2019 (COVID-19).

Sampai saat ini, situasi COVID-19 di tingkat global maupun nasional masih dalam risiko sangat tinggi. Selama pengembangan vaksin masih dalam proses, dunia dihadapkan pada kenyataan untuk mempersiapkan diri hidup berdampingan dengan COVID-19. Oleh karenanya diperlukan pedoman dalam upaya pencegahan dan pengendalian COVID-19 untuk memberikan panduan bagi petugas kesehatan agar tetap sehat, aman, dan produktif, dan seluruh penduduk Indonesia mendapatkan pelayanan yang sesuai standar. Pedoman pencegahan dan pengendalian COVID-19 disusun berdasarkan rekomendasi WHO yang disesuaikan dengan perkembangan pandemi COVID-19, dan ketentuan peraturan perundangundangan yang berlaku.

\section{Cara Penyebaran Virus Covid-19}

Menurut World Healt Organization (WHO), terdapat empat cara penyebaran Virus Covid- 19 yaitu

1. Transmisi Droplet

Transmisi SARS-CoV-2 dapat terjadi melalui kontak langsung, kontak tidak langsung, atau kontak erat dengan orang yang terinfeksi melalui sekresi seperti air 
Loyalitas Kreativitas

Aldi Masyarakat Kreatif
P-ISSN 2722-2101, E-ISSN 2722-4201

Program Studi Ekonomi Manajemen Universitas Pamulang

Jurnal LOKABMAS Kreatif Vol.02,No.03.Nov 2021 Hal.52-64

Email:jurnalkreatif.manajemen@gmail.com liur dan sekresi saluran pernapasan atau droplet saluran napas yang keluar saat orang yang terinfeksi batuk, bersin, berbicara, atau menyanyi, droplet saluran napas yang mengandung virus dapat mencapai mulut, hidung, mata orang yang rentan dan dapat menimbulkan infeksi. Transmisi kontak tidak langsung di mana terjadi kontak antara inang yang rentan dengan benda atau permukaan yang terkontaminasi (transmisi fomit) juga dapat terjadi.

\section{Transmisi Udara}

Transmisi melalui udara didefinisikan sebagai penyebaran agen infeksius yang diakibatkan oleh penyebaran droplet nuclei (aerosol) yang tetap infeksius saat melayang di udara dan bergerak hingga jarak yang jauh. Transmisi SARS-CoV-2 melalui udara dapat terjadi selama pelaksanaan prosedur medis yang menghasilkan aerosol ("prosedur yang menghasilkan aerosol"). WHO, bersama dengan kalangan ilmuwan, terus secara aktif mendiskusikan dan mengevaluasi apakah SARS-CoV-2 juga dapat menyebar melalui aerosol, di mana prosedur yang menghasilkan aerosol tidak dilakukan terutama di tempat dalam ruangan dengan ventilasi yang buruk (Asadi, 2019).

\section{Transmisi Formit}

Sekresi saluran pernapasan atau droplet yang dikeluarkan oleh orang yang terinfeksi dapat mengontaminasi permukaan dan benda, sehingga terbentuk fomit (permukaan yang terkontaminasi). Virus dan/atau SARSCoV-2 yang hidup dan terdeteksi melalui RTPCR dapat ditemui di permukaanpermukaan tersebut selama berjam-jam hingga berhari- hari, tergantung lingkungan sekitarnya (termasuk suhu dan kelembapan) dan jenis permukaan. Karena itu, transmisi juga dapat terjadi secara tidak langsung melalui lingkungan sekitar atau bendabenda yang terkontaminasi virus dari orang yang terinfeksi (misalnya, stetoskop atau termometer), yang dilanjutkan dengan sentuhan pada mulut, hidung, atau mata.

\section{Transmisi Lainnya}

Bukti sampai saat ini menunjukkan bahwa SARS-CoV-2 paling miripdengan betacoronavirus pada kelelawar yang diketahui; peran inang perantara dalam memfasilitasi transmisi pada kasus-kasus manusia paling awal yang diketahui masih belum jelas. Selain penelitian tentang kemungkinan inang(-inang) perantara SARS-CoV-2, sejumlah penelitian sedang dilakukan untuk lebih memahami kerentanan mamalia, termasuk anjing, kucing dan cerpelai ternak. Namun, masih belum jelas apakah mamalia-mamalia ini jika terinfeksi memberikan risiko transmisi ke manusia yang signifikan.

\section{Realisasi Pemecahan Masalah}

Dari uraian analisis situasi, maka dapat dibuat kerangka pemecahan masalah yang dihadapi sebagai berikut :

1. Melakukan studi pustaka tentang Sosialisasi Dan Sosialisasi Pemanfaatan Youtube sebagai media pembelajaran kreatif tanpa batas.

2. Melakukan persiapan alat dan bahan untuk penyuluhan yang bertempat di Yayasan Al-Kamilah yang berlokasi di Jl.Serua Raya Rt 03 Rw 05, kel. Serua, Kec. Bojongsari - Depok.

3. Menentukan waktu pelaksanaan dan lamanya kegiatan pengabdian bersamasama tim pelaksana

4. Menentukan dan mempersiapkan materi yang akan disampaikan dalam kegiatan pengabdian masyarakat.

\section{Khalayak Sasaran}

Yang menjadi sasaran dalam kegiatan PKM ini adalah :

Yang berjumlah 26 orang yang mengikuti sosialisasi cara Pemanfaatan youtube sebagai media pembelajaran kreatif tanpa batas ditengah pandemi covid 19 yang benar.

Tempat dan Waktu Pelaksanaan Kegiatan pengabdian kepada masyarakat (PKM) yang dilakukan oleh dosen prodi 
Loyalitas Kreativitas

Aldi Masyarakat Kreatif
P-ISSN 2722-2101, E-ISSN 2722-4201

Program Studi Ekonomi Manajemen Universitas Pamulang

Jurnal LOKABMAS Kreatif Vol.02,No.03.Nov 2021 Hal.52-64

Email:jurnalkreatif.manajemen@gmail.com
Manajemen Universitas Pamulang ini dilaksanakan pada :

Tempat : Yayasan Al-Kamilah yang berlokasi di Jl.Serua Raya Rt 03 Rw 05, kel. Serua, Kec. Bojongsari - Depok. Waktu : Tanggal 24-25 April 2021.

\section{Metode Kegiatan}

Metode kegiatan yang digunakan kepada anggota Yayasan Al-Kamilah yang berlokasi di Jl.Serua Raya Rt 03 Rw 05, kel. Serua, Kec. Bojongsari - Depok adalah berupa penyuluhan, selanjutnya mereka akan diberikan sesi tanya jawab tentang masalah yang dihadapi baik sifatnya pribadi maupun umum.

Untuk menghadapi permasalahan di atas dengan menggunakan berbagai metode, diantaranya metode dalam kegiatan ini merupakan pemberian sosialisasi dan langkah-langkah pencegahan penyebaran Covid-19, dengan melalui beberapa tahapan, adapun tahapannya yaitu:

1. Survei tempat pelaksanaan kegiatan, ini dimaksudkan untuk menggali informasi tentang kondisi geografis dan kondisi masyarakat didaerah tempat kegiatan. Informasi tersebut berupa lokasi, permasalahan yang dihadapi dalam pada lokasi tersebut.

2. Persiapan sarana dan prasarana, ini dimaksudkan untuk merencanakan kebutuhan baik sarana dan prasarana yang akan digunakan dalam pelaksanaan kegiatan dengan tetap memperhatikan kebutuhan masyarakat secara umum dan khusus demi tercapainya target pengabdian kepada masyarakat. Sarana dan prasarana yang dimaksud berupa projektor, spanduk dan lain-lain.

3. Pelaksanaan kegiatan dilakukan adalah berupa penyuluhan dalam bentuk pertemuan secara langsung dan pembagian sembako yang bertempat di Yayasan Al-Kamilah yang berlokasi di Jl.Serua Raya Rt $03 \mathrm{Rw}$ 05, kel. Serua, Kec. Bojongsari - Depok yang menitik beratkan pada Sosialisasi pemanfaatan youtube sebagai media pembelajaran kreatif tanpa batas Dan
Penerapan Sebagai Upaya Pencegahan dan Memutus Penyebaran Virus Covid-19. 4. Monitoring dan evaluasi ini
dimaksudkan untuk perkembangan aktualisasi masyarakat terhadap kegiatan yang telah dilakukan sebelumnya dengan harapan dapat dilaksanakan sesuai dengan teori yang telah di peroleh melalui kegiatan yang telah dilaksanakan. Evaluasi juga bertujuan untuk memahami pola pemahaman masyarakat terhadap informasi baru yang diperoleh dari pelaksana kegiatan. Hasil ini diharapkan mampu menjadi dasar Sosialisasi terhadap pembelajaran DARING dengan pemanfaatan youtube sebagai media pembelajaran kreatif tanpa batas guna memutus mata rantai di lingkungan Yayasan Al-Kamilah dan masyarakat sekitarnya.

\section{HASIL DAN PEMBAHASAN}
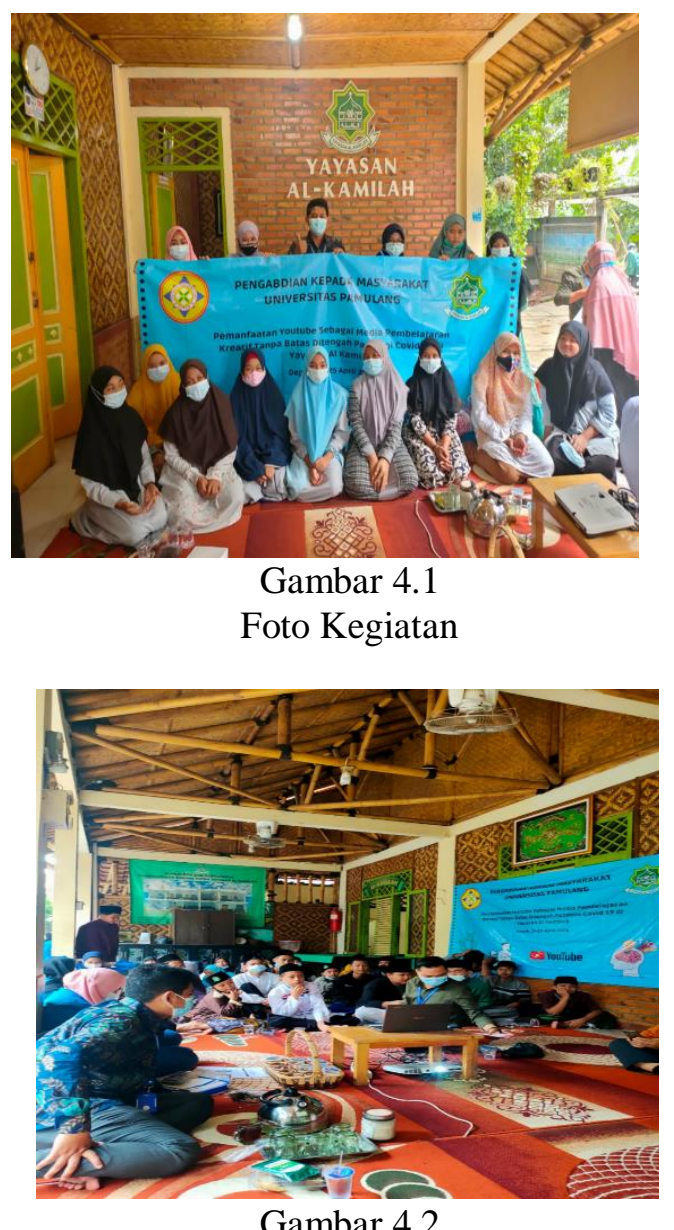


\section{Penyampaian Materi}

Kegiatan sosialisasi dan penerapan di Yayasan Al-Kamilah sosialisasi pemanfaatan youtube sebagai media pembelajaran kreatif tanpa batas Sebagai Upaya Memutus Mata Rantai Penyebaran Covid-19 di Yayasan Al-Kamilah Jl.Serua Raya Rt 03 Rw 05, kel. Serua, Kec. Bojongsari - Depok. Yang berjumlah 26 peserta.

Kegiatan penyuluhan dan pembinaa ini dimulai dengan sambutan dari ketua pelaksana dan dari pihak Yayasan AlKamilah yaitu selanjutnya perkenalan anggota pengabdian kepada masyarakat dan juga para anggota Yayasan Al-Kamilah di Jl. Serua Raya Rt 03 Rw 05, Kelurahan. Serua Kecamatan. Bojongsari - Depok tujuannya untuk membuat suasana lebih akrab. Setelah itu, pemateri menayangkan slide power point yang berkaitan dengan materi Pemanfaatan Youtube Sebagai Media Pembelajaran Kreatif Tanpa Batas Dimasa Pandemi Covid-19. Respon dari Yayasan Al-Kamilah itu sendiri sangat baik. Terlihat ketika pemateri menanyakan Penerapan dan Sosialisasi Belajar Daring dengan Pemanfaatan Youtube sebagai media pembelajaran kreatif tanpa batas ke salah satu anggota Yayasan Al-Kamilah respon yang diberikan cepat menangkap dan dengan mudah menerima pengetahuan dari materi tersebut.

Alhamdulillah kegiatan sosialisasi dan Cara pembelajaran daring dengan Pemanfaatan Youtube sebagai media pembelajaran kreatif tanpa batas guna memutus mata rantai covid-19 berjalan cukup baik, karena semua peserta sangat merespon dengan baik dalam kegiatan ini. Berdasarkan wawancara, tanya jawab dalam kegiatan tersebut ada beberapa perubahan yang dilihat dari para anggota Yayasan AlKamilah yang mengikuti kegiatan sosialisasi dan cara pembelajaran daring dengan Pemanfaatan Youtube sebagai media pembelajaran kreatif tanpa batas sebagai upaya pencegahan penyebaran virus covid 19. Dengan pengamatan langsung selama kegiatan berlangsung, kegiatan pengabdian kepada masyarakat ini memberikan hasil sebagai berikut :

1. Meningkatkan pengetahuan dan kemampuan individu agar mau dan mampu mengambil tindakan yang dapat meningkatkan dan memelihara kesehatannya.

2. Menyiapkan akses terhadap sarana yang diperlukan untuk praktik belajar Daring dengan Pemanfaatan Youtube sebagai media pembelajaran kreatif tanpa batas di tempat tinggal maupun di lingkungan sekitar dan sekolah.

3. Mengidentifikasi kebiasaan keluarga dan masyarakat yang menghalangi mereka agar selalu memakai masker dan menggunkan hand sanitizer agar memutus upaya penyebaran covid19 dan selalu berperilaku hidup bersih dan sehat.

4. Merubah pandangan tentang Pemakaian Masker dan Hand sanitizer yan baik dan benar dengan melibatkan berbagai tokoh di masyarakat.

5. Menyediakan informasi tentang pembelajaran Daring dengan Pemanfaatan Youtube sebagai media pembelajaran kreatif tanpa batas.

\section{KESIMPULAN DAN SARAN Kesimpulan}

Pelaksanaan kegiatan Pengabdian Kepada Masyarakat oleh Lembaga Penelitian dan Pengabdian Masyarakat (LPPM) Universitas Pamulang yang dilakukan oleh dosen-dosen program studi Manajemen telah berjalan dengan lancar dan mendapat sambutan hangat dari tempat pelaksanaan kegiatan ini yaitu dilakukan pada Yayasan Al-Kamilah Jl. Serua Raya Rt 03 Rw 05, Kelurahan. Serua Kecamatan. Bojongsari Depok, yang berjumlah 26 peserta.

Harapan kami dengan pengabdian ini dapat membuka wawasan dari pada Yayasan AlKamilah Jl. Serua Raya Rt 03 Rw 05, Kelurahan. Serua Kecamatan. Bojongsari - Depok Sebagai Upaya Pencegahan Penyebaran Virus Covid-19. Materi yang kami berikan yaitu Pemanfaatan Youtube Sebagai Media Pembelajaran Kreatif Tanpa Batas Ditengah Pandemi Covid 19 di Yayasan Al-Kamilah.

Tata cara Dan Pendeskripsian belajar secara daring dengan Pemanfaatan Youtube Sebagai Media Pembelajaran Kreatif Tanpa Batas ini memberikan gambaran bahwa perkembangan zaman akan terus menimbulkan kemajuan, 
Loyalitas Kreativitas

Aldi Masyarakat Kreatif
P-ISSN 2722-2101, E-ISSN 2722-4201

Program Studi Ekonomi Manajemen Universitas Pamulang

Jurnal LOKABMAS Kreatif Vol.02,No.03.Nov 2021 Hal.52-64

Email:jurnalkreatif.manajemen@gmail.com terutama dalam bidang teknologi. Kecanggihan teknologi pada saat pandemi seperti sekarang sangat dibutuhkan baik oleh pengajar atau dosen maupun penerima materi yakni peserta didik / siswa atau mahasiswa. Dilarangnya pembelajaran secara tatap muka menjadikan youtube sebagai media pembelajaran alternative. Youtube memberikan informasi berbeda yakni lebih jelas karena biasanya bersifat audio-visual berbeda dengan Google yang hanya memberikan informasi dengan kata-kata saja.

Kelebihan lain dari Youtube diantaranya adalah, orang yang menyimak materi pembelajaran tidak akan ada kata tertinggal materi, karena bisa diakses lagi dan diputar ulang, berbeda dengan pembelajaran secara konvensional. Pembelajaran dengan cara konvensional, ketika peserta didik tertinggal materi dia tidak dapat mengulang kembali materi yang disampaikan oleh pengajarnya. Pemilihan media pembelajaran menggunakan Youtube dikala ada pandemi Covid-19 menjadi pilihan karena peserta didik seolah-olah, bertemu dengan pengajarnya, bisa menyimak apa yang disampaikan oleh pengajar, bisa mengulangulang materi yang disampaikan serta peserta didik menjadi tidak bosan ketika hanya diberikan materi berupa tulisan saja.

Hal ini juga menjadikan tantangan bagi para pengajar untuk memberikan konten yang menarik dalam video pembelajarannya. Meskipun media pembelajaran menggunakan Youtube cukup menarik, pengajar pun perlu mencari cara lainnya yakni mengembangkan pembelajaran agar tetap bisa interaktif yakni terjadi komunikasi dua arah antara pengajar dan peserta didik. Dengan begitu, akan tercipta pola dan tatanan yang teratur guna memutus mata rantai covid-19.

Dalam laporan kegiatan ini mungkin banyak kekurangan yang ada, untuk itu kami berharap masukan dan kritikan dalam rangka perbaikan untuk kegiatan-kegiatan pengabdian masyarakat di masa yang akan datang. Semoga kegiatan pengabdian masyarakat ini dapat bermanfaat bagi masyarakat sekitar lingkungan Universitas Pamulang dan lainnya.

Akhirnya, kami mengucapkan banyak terimakasih kepada seluruh pihak yang telah mendukung dan berkontribusi dalam kegiatan PKM ini dan kami memohon maaf apabila dalam kegiatan PKM ini banyak ditemukan kekurangan dan kesalahan.

\section{Saran}

Berdasarkan hasil kegiatan PKM yang sudah dilakukan, maka kami dari team Dosen Universitas Pamulang memberikan saran yaitu sebagai berikut :

1. Mengadakan penyuluhan dan pembinaan serupa pada Yayasan lainnya ataupun pada masyarakat siswa sekolah lain dengan materi yang sama.

2. Adanya kesinambungan program pasca kegiatan pengabdian ini sehingga masyarakat benar-benar dapat termotivasi untuk mempraktikkan perilaku hidup bersih dan sehat.

3. Untuk Masyarakat: Bisa memakai Masker dan Hand Sanitizer yang baik dan benar karena selama ini masyarakat banyak yang belum bisa memakai masker dan hand sanitizer yang tepat, agar dapat meningkatkan perilaku hidup bersih dan sehat yang baik, Melakukan pemantauan berkala pada lingkungan masyarakat, agar berperilaku bersih dan sehat dengan mengurangi risiko dengan mencuci dengan sabun dan air yang mengalir, kurangi Kontak Langsung (Physical Distancing).

4. Perlunya peningkatan dukungan sarana dan prasarana untuk memanfaatkan TIK di sekolah, universitas dan tempat belajar lainnya, sehingga kesiapan pembelajaran dengan menggunakan Youtube dapat lebih dimaksimalkan.

\section{DAFTAR PUSTAKA}

Anggraini, R. D. (2018). Pemanfaatan YouTube Sebagai Media Pembelajaran dalam Meningkatkan Kreatifitas Guru Bahasa Inggris Mts Al-Insan. Universitas Muhammadiyah Tanggerang, 446-452.

DF Wilandari, H Hasanudin, RP Anggraeni, Sosialisasi Cara Pemakaian Masker dan Hand Sanitizer yang Baik Sebagai Upaya Memutus Mata Rantai Penyebaran Covid-19 Di Rumah Pintar Komplek Griya Asri 
Loyalitas Kreativitas

Aldi Masyarakat Kreatif
P-ISSN 2722-2101, E-ISSN 2722-4201

Program Studi Ekonomi Manajemen Universitas Pamulang Jurnal LOKABMAS Kreatif Vol.02,No.03.Nov 2021 Hal.52-64 Email:jurnalkreatif.manajemen@gmail.com
Pamulang, Blok E 9 No.7 kecamatan Setu Kelurahan Bhakti Jaya, Jurnal Lokabmas Kreatif: Loyalitas Kreatifitas Abdi, 2021

Elburdah, R. P., Pasaribu, V. L. D., Rahayu, S., Septiani, F., \& Metarini, R. R. A. (2021). MOMPRENEUR PENOPANG PEREKONOMIAN KELUARGA DI MASA PANDEMI COVID-19 DENGAN BISNIS ONLINE PADA KELURAHAN PONDOK BENDA. Abdi Laksana: Jurnal Pengabdian Kepada Masyarakat, 2(1), 75-82

Faiqah, F., Nadjib, M., \& Amir, A. S. (2017). Youtube Sebagai Sarana Komunikasi Bagi Komunitas Makassarvidgram. KAREBA: Jurnal Ilmu Komunikasi, 5(2), 259-272

Handayani, M. (2020). ANALISIS DESKRIPTIF FAKTOR PENGHAMBAT PEMBELAJARAN DARING DALAM PENINGKATAN KEMAMPUAN BERPIKIR KRITIS SISWA KELAS IV DI SEKOLAH DASAR (Doctoral dissertation, Universitas Pendidikan Indonesia).

Rigianti, H. A. (2020). Kendala Pembelajaran Daring Guru Sekolah Dasar di Banjarnegara. Elementary School: Jurnal Pendidikan dan Pembelajaran keSD-an, 7(2).Riyana, C. (2019). Produksi Bahan Pembelajaran Berbasis Online. Universitas Terbuka.

Pasaribu, V. L. D., Agrasadya, A., Shabrina, N., \& Krisnaldy, K. (2020). Menjadi Enterpreneur Muda Yang Memiliki Jiwa Leadership Untuk Menghadapi Masa Depan. Abdi Laksana: Jurnal Pengabdian Kepada
Masyarakat, 1(1).

Pasaribu, V. L. D., Susanti, F., \& Hartuti, E. T. K. (2019). Memotivasi Siswa dan Siswi SMK Letris Indonesia di Dalam Menentukan Pilihan Untuk Melanjutkan Pendidikan Atau Bekerja Setelah Lulus Sekolah. Jurnal Pengabdian Dharma Laksana, 1(2), 161-172.

Pasaribu, V. L. D., Sulaiman, S., Sutiman, S., Thaharudin, T., \& Purnomo, B. Y. (2020). Pengenalan Letak Posyandu Terdekat Dikelurahan Pisangan Dengan Manajemen Pemasaran Revolusi 4.0 Untuk Meningkatkan Pengetahuan Masyarakat Letak Dan Fungsi Posyandu Terdekat Pada Kelurahan Pisangan. Dedikasi Pkm, 1(1), 105110.

Pasaribu, V. L. D., Oktrima, B., Prabowo, B., Arianto, N., \& Haryoko, U. B. (2020). Progam Pendampingan Dan Penyelenggaraan Pendidikan Anak Pada Usia Dini Terhadap Prestasi Belajar Dilingkungan Rt 020 Rw 009. Kel Giri Peni. Kec Wates. Yogyakarta. Jurnal Lokabmas Kreatif, 1(1), 71-75.

Pasaribu, V. L. D., Jannah, M., Fazar, M., Putra, S. P., Monalisa, M., \& Sofa, M. (2021). MENINGKATKAN PRODUKTIVITAS USAHA DIMASA PANDEMI PADA IBU PKK RT 004/003 KELURAHAN SAWAH BARU CIPUTAT, TANGERANG SELATAN. Abdi Laksana: Jurnal Pengabdian Kepada Masyarakat, 2(2), 295-301 
Loyalitas Kreativitas

Aldi Masyarakat Kreatif
P-ISSN 2722-2101, E-ISSN 2722-4201

Program Studi Ekonomi Manajemen Universitas Pamulang Jurnal LOKABMAS Kreatif Vol.02,No.03.Nov 2021 Hal.52-64 Email:jurnalkreatif.manajemen@gmail.com
Pasaribu, V. L. D., Yuniati, H. L., Pranata, R., Sembayu, R., Purba, S. M., \& Nurbayani, T. T. A. (2021). MANAJEMEN KEUANGAN UNTUK MENGHADAPI DAN BERTAHAN DI ERA COVID 19. Jurnal Abdimas Tri Dharma Manajemen, 2(2), 12-18.

Pasaribu, V. L. D., Dwiyatni, A., Sabina, C., Ridwan, M., Gunawan, D. D., \& Noviani, B. C. (2021). EVALUASI PENERAPAN 3M DIMASA PANDEMIC COVID 19. Jurnal Abdimas Tri Dharma Manajemen, 2(2), 54-60.

Pasaribu, V. L. D., Syafei, A. N., Farhan, A., Aufaizah, A., Irani, C., \& Firtiayani, S. R. (2021). PENGARUH DISPLIN PROTOKOL KESEHATAN TERHADAP PENCEGAHAN PENULARAN VIRUS COVID19. Jurnal Abdimas Tri Dharma Manajemen, 2(2), 91-98.

Pasaribu, V. L. D., Septiani, F., Rahayu, S., Lismiatun, L., Arief, M., Juanda, A., ... \& Rahim, R. (2021). Forecast Analysis of Gross Regional Domestic Product based on the Linear Regression Algorithm Technique.

Pasaribu, V. L. D., Priadi, A., Anismadiyah, V., Rahayu, S., \& Maduningtias, L. (2021). PENYULUHAN KREATIF DAN INOVATIF MENINGKATKAN MUTU PRODUKSI UMKM DI DESA BELEGA KABUPATEN GIANYAR. Pro Bono Jurnal

$$
\begin{aligned}
& \text { Pengabdian } \\
& \text { Masyarakat, 1(02). }
\end{aligned}
$$

Kepada

Pasaribu, V. L. D. (2021). PELATIHAN BERBASIS ONLINE DI ERA COVID-19. Jurnal Abdimas Tri Dharma Manajemen, 2(3), 26-32.

Pasaribu, V. L. D., \& Setyowati, R. (2021). ADAPTASI KEHIDUPAN NEW NORMAL PADA MASA PANDEMI COVID-19 DIYAYASAN PONDOK PESANTREN DAN PANTI ASUHAN NURUL IKHSAN KECAMATAN SETU, KOTA TANGERANG SELATAN. Jurnal Lokabmas Kreatif: Loyalitas Kreatifitas Abdi Masyarakat Kreatif, 2(2), 82-88.

Priadi, A., Pasaribu, V. L. D., Virby, S., Sairin, S., \& Wardani, W. G. (2020). Penguatan Ekonomi Kreatif Berbasis Sumber Daya Desa Dikelurahan Rempoa. Abdi Laksana: Jurnal Pengabdian Kepada Masyarakat, 1(3), 356-35

Susanti, F., Ratnawati, W., \& ivan Jazwita, D. (2020). Literasi Digital Facebook dan Whatsapp terhadap Motivasi Belajar Generasi Milenial. Jurnal Lokabmas Kreatif: Loyalitas Kreatifitas Abdi Masyarakat Kreatif, 1(2), 35-40.

Susanti, F., Lisdawati, L., Andini, R., Setiawan, R., \& Ratnawati, W. (2020). Menanamkan Jiwa dan Semangat Kewirausahaan Persaingan Menghadapi di Era Globalisasi pada Guru dan Orangtua Murid Bimbingan Belajar Bimba Pamulang Tangerang 
Loyalitas Kreativitas

Aldi Masyarakat Kreatif
P-ISSN 2722-2101, E-ISSN 2722-4201

Program Studi Ekonomi Manajemen Universitas Pamulang

Jurnal LOKABMAS Kreatif Vol.02,No.03.Nov 2021 Hal.52-64

Email:jurnalkreatif.manajemen@gmail.com

Selatan. DEDIKASI PKM, 1(1), 95-

100.

Susanti, F., Jaswita, D. I., \& Mardiana, S.

$\begin{array}{lr}\text { (2020). PENGEMBANGAN } \\ \text { POTENSI } & \text { EKONOMI } \\ \text { KEWIRAUSAHAAN } & \text { IBU } \\ \text { RUMAH TANGGA } & \text { DALAM } \\ \text { MENINGKATKAN } & \text { EKONOMI } \\ \text { MASYARAKAT } & \text { KELURAHAN } \\ \text { CEMPAKA } & \text { PUTIH } \\ \text { CIPUTAT. Jurnal } & \text { Lokabmas }\end{array}$

Kreatif: Loyalitas Kreatifitas Abdi

Masyarakat Kreatif, 1(1), 89-95.

https://www.antaranews.com/berita/1635246/me

nguji-kreativitas-guru-dalam-pembelajaran-

jarak-jauh-saat-pandemi

https://www.antaranews.com/berita/1536116/pa

kar-kreativitas-guru-tentukan-kualitas-

pendidikan-di-masa-pandemi

https://kotakpintar.com/pengertian-kreatif-dan-

kreativitas/

https://www.google.com/search?q=pengertian+k reatif+menurut+para+ahli\&oq=pengertian+kreat if $+\&$ aqs $=$ chrome.3.69i57j019.12116j0j7\&sourcei $\mathrm{d}=$ chrome $\& \mathrm{ie}=\mathrm{UTF}-8$ 